\title{
Tilapia Stock Suppression by the Great Cormorant (Phalacrocorax carbo) in Lake Kinneret, Israel
}

\author{
Moshe Gophen \\ Scientific Research Institute in the Galilee, Kiryat Shmone, Israel \\ Email: Gophen@Migal.org.il
}

How to cite this paper: Gophen, M. (2017) Tilapia Stock Suppression by the Great Cormorant (Phalacrocorax carbo) in Lake Kinneret, Israel. Open Journal of Modern $\mathrm{Hy}$ drology, 7, 153-164.

https://doi.org/10.4236/ojmh.2017.72009

Received: March 19, 2017

Accepted: April 18, 2017

Published: April 21, 2017

Copyright $\odot 2017$ by author and Scientific Research Publishing Inc. This work is licensed under the Creative Commons Attribution International License (CC BY 4.0).

http://creativecommons.org/licenses/by/4.0/

(c) (i) Open Access

\begin{abstract}
The Great Cormorant (Phalcrocorax carbo sinensis) is a well-known fish predator and migratory bird. The bird is a wintering visitor in Israel from the end of October through March. During 1950-1990, the Cormorant used to stay mostly in northern Israel, in the Hula Valley, preying on fish in Lake Kinneret as well as fishponds and adjacent reservoirs. Flocks of Cormorants were deported from northern Israel to eastern and central country regions, causing severe damage to aquaculture. A second operative deportation was carried out and the birds migrated to Lake Kinneret. A survey of their feeding habits was done by The National Nature and Parks Conservation Authority. The outcome information was compiled with international data and assembled towards a conclusive summary of potential causative damage to Lake Kinneret Fishery and Ecosystem structure. Consequences are described and recommendations made.
\end{abstract}

\section{Keywords}

Great Cormorant, Fish Predation, Lake Kinneret

\section{Introduction}

\section{Cormorants in Israel}

The Great Cormorant (Photo 1 and Photo 2) is included in the Avifauna of Israel. The old shallow lake Hula located north of Kinneret was densely populated by Cormorants (Photo 1). Fish aquaculture development in the Hula Valley (northern part of Israel) attracted Cormorants to the region and fish predation by them was intense. During 1950-1990 cormorants densely populated the Hula valley causing damage to aquaculture and to the Tilapia populations in 


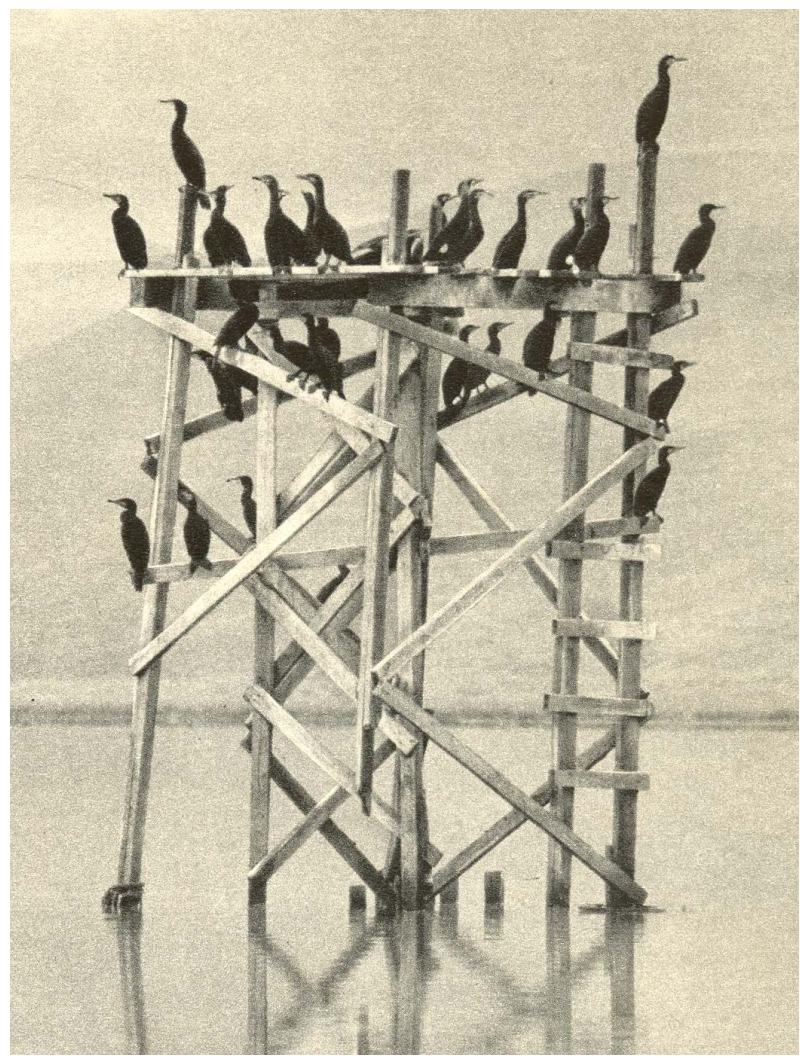

Photo 1. Cormorants in the old Hula Lake. Photo Source: P. Merom.

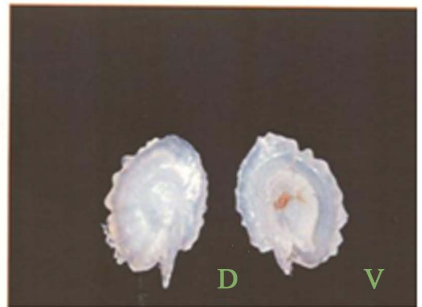

Bleak

Length: $3.5 \mathrm{~mm}$

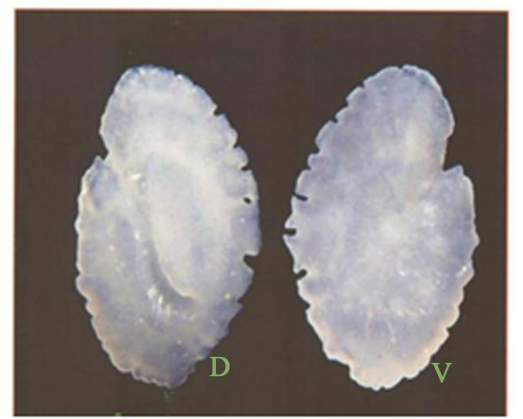

Sarotherodon

galilaeus

Length: $7.5 \mathrm{~mm}$

Photo 2. Microscopical photo of Lake Kinneret Fish Otolithes. Source: Y. Artzi.

Lake Kinneret. However, a successful deportation of them in the north enhanced inland migration to other parts of the country. Active deportation of Cormorants by the farmers was carried out again and the birds found a refuge in Lake Kinneret. The Great Cormorant (Phalacrocorax carbo) is a worldwide wellknown migratory fish predator bird. The migration of the Cormorant to Israel is part of a routine annual cyclic behavior. Cormorants stay in Israel during November-March. They migrate from Europe and leave Israel back to European countries where they breed during Spring-Summer. Prior to the drainage of the old Lake Hula and the wetlands in the vicinity, the Cormorant stayed in the Hula 
Valley (Photo 1), whilst during 1960-1990 a major part of the population maintained a daily migration to adjacent reservoirs and Lake Kinneret. A minor part of the Cormorants also populated the Mediterranean coastal zone. During the period of 1960-1990, the major fish predation pressure was achieved on fish ponds and reservoirs in the coastal plain, the Hula, Jordan and the Beith-Shean Valley and Lake Kinneret. National Fish Breeders Organization operated deportation of Cormorants from Fish-Pond regions to find a protected refuge in Lake Kinneret. The outcome of that policy created a situation of one food resource for them, Lake Kinneret, and several night-stay sites in the vicinity. That was a shift from aquaculture damage to disturbance to the Kinneret ecosystem management.

Fishermen and fishery managers consider Cormorants as a competitor. The conflict between Cormorants and fisheries, especially when integrated into lake management design, is a wide internationally known issue. Cormorant damages to fishery and lake management are drastic not only in Europe but in other parts of the world as well [1] [2]. The Cormorant population in Europe has increased during the last 25 years due to the implementation of endangered birds' protection policy adopted by the European Economic Community (EEC). An International workshop was organized by FAO-EIFAC in Brussels [3]. Representatives from 24 European countries attended (FAO/EIFAC 2008; Carss, 2002). The final report was completed in 2008 (FAO/EIFAC 2008). This workshop concept included the need for long-term sustainability proposal of aquatic ecosystems and aquaculture under the threat of predation damage caused to fish by Cormorants. The increase of the Cormorant population during the last 25 years to 1.8 million birds was accompanied by severe damages to aquaculture and lake ecosystems. During 1960-1995 there was, in Holland, an increase from 800 to more than 150,000 breeding couples due to the only one reason of protected animal status that was given to the Cormorants by the EEC (European Economic Community). The EEC authorities approximated the European economy's annual damage as 17 million Euros per year. Irreversible damages to terrestrial vegetation also resulted. The lack of an international program for research and monitoring with consequent instructions for appropriate management was prominent and thoroughly discussed in international forums. The FAO/EIFAC [3] final recommended resolution [3] included, among other things, legally shooting about 43,000 birds annually but not more than 4600 during the breeding season. From the year 1997 shooting Cormorants is legitimately permitted because this bird lost its protected status in European countries. An international workshop organized by the European Inland Fisheries Advisory (EIFA) (29 countries delegators) was held in Germany in 2007 aimed at promoting the prevention of fish predation by birds.

Awareness about the potential damage to the Kinneret ecosystem by Cormorants was recently initiated. The Nature Protection Authority (NPA) carried out a survey on the population density of Cormorants, their daily migration, feeding rate and food composition [4]. The objective of the present study is to summar- 
ize available international and national information aimed at indicating potential deterioration of the Kinneret Ecosystem structure and fisheries by the Cormorant.

The practical significance of the presented paper is the need to implement the concept of nature protection on one side and improvement of management operation of Lake Kinneret. Although the issue resembles a contradiction between those two objectives, a reasonable gap bridging contact is predicted.

\section{Methods}

A survey of feeding habits, population density of the Great Cormorant (Phalacrocorax carbo) in the Lake Kinneret region was carried out during 2010-2012. The documented results were published in 2011 [4] and revised in 2012. A study of the feeding rate and composition was carried out by a collection of freshly egested pellets (regurgitated) of the Cormorant underneath Eucalyptus trees in the vicinity to the most northern end of Lake Kinneret at the Jordan inlet zone. The pellets were analysed microscopically by identify and count Otholites in each one of them. The number of preyed fishes was estimated by considering the number of Otolithes counted per pellet (each individual fish has 2 Otolithesd) (Photo 2). The number of ingested fishes per individual bird was averaged, with SD calculations of all sampled pellets per month (Table 1). These groups of trees are utilized by the birds as night stay site. Pellets are egested as regurgitated particles by the Cormorants in the early morning and freshly collected. There were hard bony-calcified body parts of daily preyed fish, which are not digested and therefore regurgitated every day at early morning. Among those body parts the Otolithes (Photo 2) are indicative of the fish species and size. Based on this method the NPA report has indicated partially reliable data. Cormorant density was supported by early morning counts of birds upon flocks leaving the night stay site towards day feeding activity in Lake Kinneret (M. Lev, J. Shapiro, Y. Fdida, O. Sonin, Z. Snovsky, personal communication).

Additional information about Cormorant densities was supplied by fishermen observing several flock flights arriving at the lake from several southern and eastern night stay sites.

In the early 1990's a survey was carried out on the content of Cormorant gut by shooting 60 birds during daytime and doing a gut content analysis.

A literature survey was implemented from which critical information was taken: daily ration by energetic budget indication of birds in captivity; daily counts of regurgitated activity during daytime; the fate of small and large Otolithes within the Cormorant's digestive system prior to vomiting; the preyed fish size selection; ecological modifications of lake ecosystems affected by Cormorants' population increase; getting International organizations to achieve suppression of ecological deterioration by Cormorants.

Fishery data in Lake Kinneret was provided by the Fishery Department, Lake Kinneret Branch, Agriculture Ministry

The Cormorant issue was initiated as a result of practical difficulties of the 
management design of water quality combined with fishery. The required outcome of the present lake situation was a compilation of the entire available information and data sources which directed the efforts towards the methods usage for the present study.

\section{Results}

\subsection{Field Observations}

The efficiency of fish predation capabilities by Cormorant in Lake Kinneret was surveyed. During November-March, flocks of several hundreds of birds each were observed landing on the water surface in Lake Kinneret, daily (Photo 3), just above fish (mostly Tilapia) shoals. Fishermen exploited efficiently those visible landing flocks as markers of fishing targets. The fish shoals are located at 3 $10 \mathrm{~m}$ deep (documented by Eco-Sounder-Fish-Finder) underneath the bird flights. The diving bird maintained its capture of fish and each dive continued for 20 - 45 seconds. Capture probability varied between 4 and 6 dives for a successful catch. Perception of a successful catch was observed when a bird got out of the water to the surface with its beak holding a fish and immediately operating head jerking aggressively to allocate the fish position appropriately as head forwarding followed by ingestion.

\subsection{Otolithes Survey [4]}

The statistical relation between the length of Otolithes (X) (Photo 2) and the length of preyed fish $(\mathrm{Y})$ was calculated as follows [4].

1) Tilapias: $\mathrm{n}=118 ; \mathrm{r}^{2}=0.9012 ; \mathrm{Y}=(0.2741 \mathrm{X})^{3.2766}$

2) Bleaks: $\mathrm{n}=30 ; \mathrm{r}^{2}=0.8492 ; \mathrm{Y}=(1.857 \mathrm{X})^{3.084}$

Percentage of prey partition by weight between Bleaks and Tilapias, average number of fish counted per pellet $( \pm S D)$, number of analyzed regurgitated particles and fish weight (g) per bird per day are given in Table 1 [4].

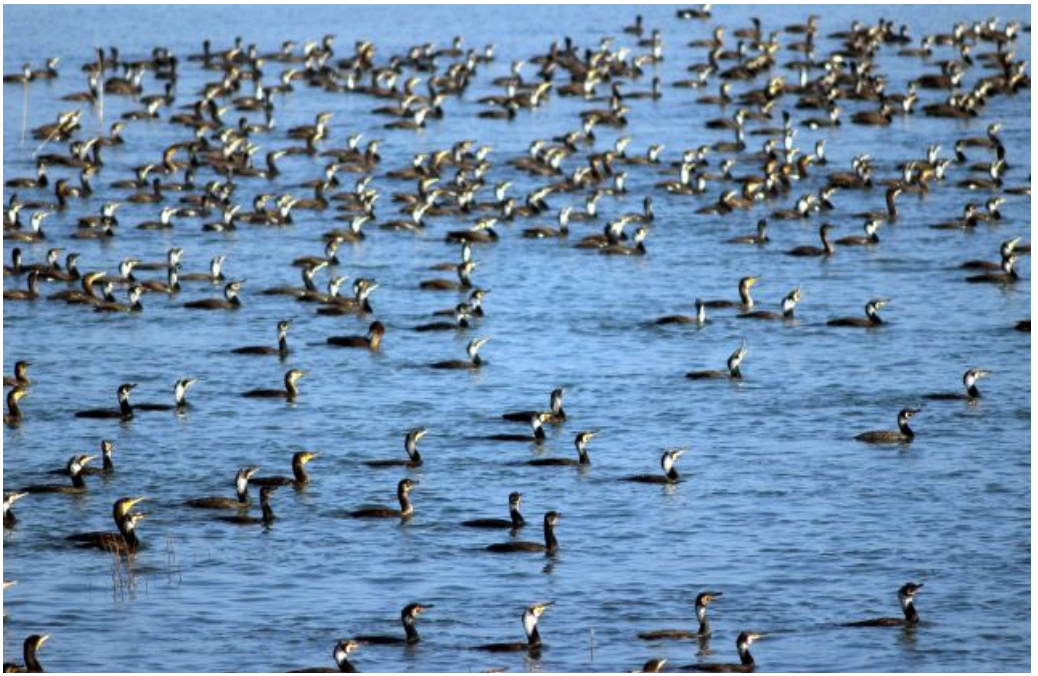

Photo 3. Cormorant Flock on Lake Kinneret During day-feeding time. (Photo Source: J. Shapiro). 
Table 1. Percentage of prey partition by weight of Bleaks and Tilapias, average number of fish counted per pellet $( \pm S D)$, number of analyzed regurgitated particles and fish weight (g) per bird per day freshly collected in the night stay site of the Cormorant in the Lake Kinneret region [4].

\begin{tabular}{cccccc}
\hline Month/Year & Tilapias (\%) & Bleaks (\%) & $\begin{array}{c}\text { Mean Fish } \\
\text { No./Regurgitation } \\
\text { Particle }( \pm \text { SD })\end{array}$ & N & Weight(g)/bird/day \\
\hline $11 / 2010$ & 58 & 42 & $7(5)$ & 25 & 250 \\
$12 / 2010$ & 50 & 50 & $11(6)$ & 93 & 300 \\
$1 / 2011$ & 51 & 49 & $13(8)$ & 94 & 350 \\
$2 / 2011$ & 69 & 31 & $8(5)$ & 65 & 400 \\
$3 / 2011$ & 90 & 10 & $5(3)$ & 30 & 399 \\
\hline
\end{tabular}

Results in Table 1 indicate that majority of preyed fish is due to Tilapias and a decline of the Bleaks part from January. The data is respective to mean weight of ingested fishes per individual Cormorant per day after value correction caused by intestinal degradation of the Otolithes. The mean TL of preyed fishes as indicated by Otolithe measurements was $138 \mathrm{~mm}$ and weight was $54 \mathrm{~g}$, and the mean weight consumption per bird per day was $342 \mathrm{~g}$, with a maximum of $1110 \mathrm{~g}$. If consumption rates were calculated without correction of degradation coefficient the seasonal daily prey ration varied between 250 and 400 (mean-330) g/bird/ day, taking into account that fishes smaller than $10 \mathrm{~cm}$ having Otolithes smaller than $2 \mathrm{~mm}$ were completely disintegrated and vanished and not observed in collected regurgitated particles. It is also prominent that, when Tilapia partition is increasing, the number of Otolithes decline because Tilapia biomass is larger. Moreover, it is suggested that during November-December captured fishes are mostly Bleaks and the higher preyed biomass during February-March is due to Tilapias, with a lower number of Otolithes per pellet. It is probably aimed at energy-reserved stocking towards close migration activity. The part of preyed fishes other than Tilapias and Bleaks, such as Balbels, Common Carp, or Silver Carp is less than $4 \%$ by weight. Among preyed Cichlids, Tilapias composed $83 \%$ - $99 \%$ by weight and Tristramellids $17 \%$ - 1\%. A survey carried out by Shkedy et al. [5] documented similar trends of seasonal changes of food composition: a seasonal increase of Tilapias and a decline of Bleaks.

Results of earlier (1996) gut content survey carried out by shooting indicated lower levels of ingested fish weights: $105 \mathrm{~g}$ and $545 \mathrm{~g}$ for average and maximum, respectively.

\section{Discussion}

Lake Kinneret is the only one natural freshwater lake in Israel. Prior to the "desalinization era" (started early 2000's) this lake was the major source of domestic water supply. Presently, domestic supply of lake water was replaced by desalinized Mediterranean waters. Nevertheless, lake services aimed at fishery, tourism, aquatic recreation and nature conservation remained crucial. Therefore, 
lake management is aimed at optimization of objectives through equilibrated policy of operation. The existence of 7000 protected Cormorants in Lake Kinneret, eating up $500 \mathrm{~g}$ of fish per bird per day of commercially desired fishes during 5 months a year, might be very attractive for bird watchers but might deteriorate fishery and water quality. Preference of one objective over another in such a multi-conceptual approach of the Kinneret ecosystem management design is representing a wrong rational. In recent years the issue of the Cormorant is not only in Lake Kinneret but also an international nuisance. For the implementation of rational preventive deportation of the Cormorant, reliable data is essential: when they migrate to and from Kinneret, how many birds stay in Kinneret and the allocation sites at night, how much fishes are consumed and preyed fish species seasonal selection.

The history of inland migration of the Cormorant in Israel confirms the adaptation capability of those birds. The reality of Unpublished information (NPA pers.com.) confirms dense populations of the Cormorant along the Mediterranean Coastal Plain and inland reservoirs. Moreover, an aggressive deportation policy that was implemented by a fish breeder organization confirms the efficient removal of the Cormorant from fish ponds.

\subsection{Fish Consumption by the Cormorant}

Several methods for the study of feeding rates of Cormorants were discussed. 1) Energetic balances based on physiological measures of birds in captivity. 2) Gut content analysis of birds killed by shooting. 3) Analysis of freshly collected fresh pellets which were egested (regurgitated) by the Cormorants in their night stay site. These pellets are egested by the birds in the early morning and immediately collected and are considered to represent the diet ingested during the previous day [6]. Great Cormorants regurgitated undigested things, including bones, scales and Otolithes which are analyzed microscopically. Otolithes are indicative of the definition of preyed fish size and species. There are several factors which cause underestimation of the actual food ingested: The birds' egestion occurs more than once a day and possibly at different sites (Photo 4); Otolithes of small fishes, are soft and are easily damaged, disintegrated and vanished [7]. The NPA survey [4] included biased assumptions: each Cormorant produces only one pellet per day and the only parameter suitable for the determination of fish number, size, and species are Otolithes; the night stay site usage (Photo 5) by Cormorants is only one. Our field observations and internationally published information partly doubted these assumptions. Duffy and Laurenson [8] justified the Otolithe method with precautionary concerns about the disintegration of small and soft Otolithes. Emmrich and Duttmann [9] recommended the usage of the Otolithe method and documented results of 562 pellets analysis where 10,645 fishes were determined including 15 species, and seasonal changes in species composition and fish size were included. Experimental studies of Cormorant feeding habits in captivity [10] was carried out. It was found that that a 7-month-old Cormorant egested pellets two times a day during 23 days and once a day during 8 days. 


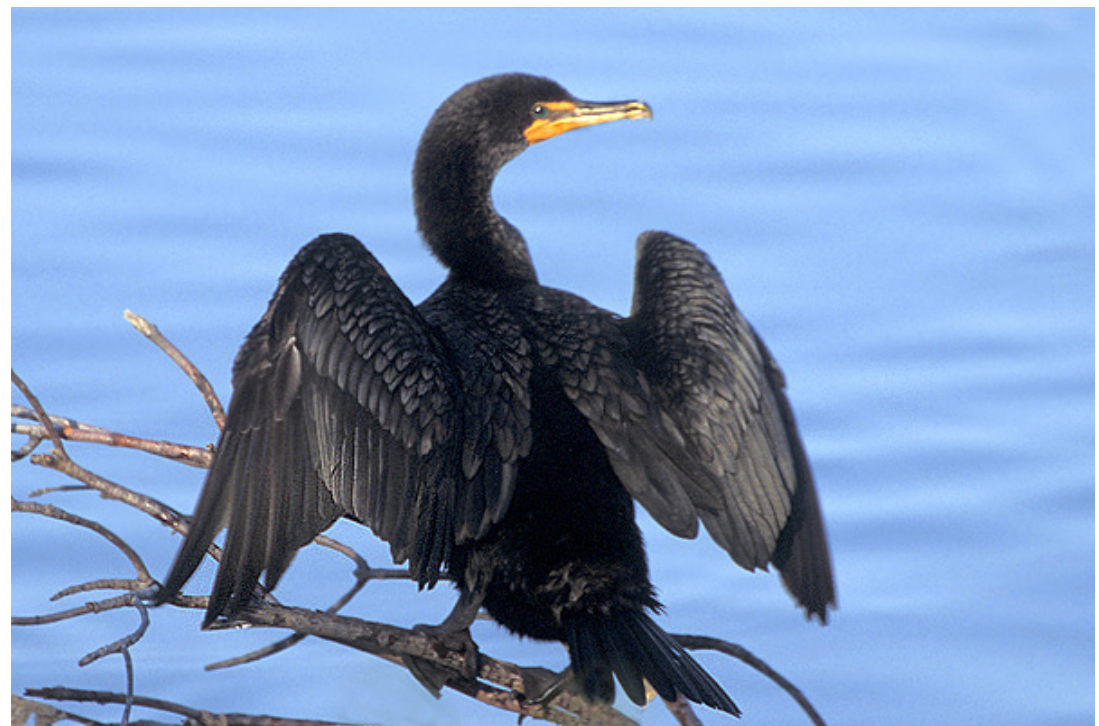

Photo 4. Cormorant drying wings during day time. (Photo Source: Anonymous, Internet).

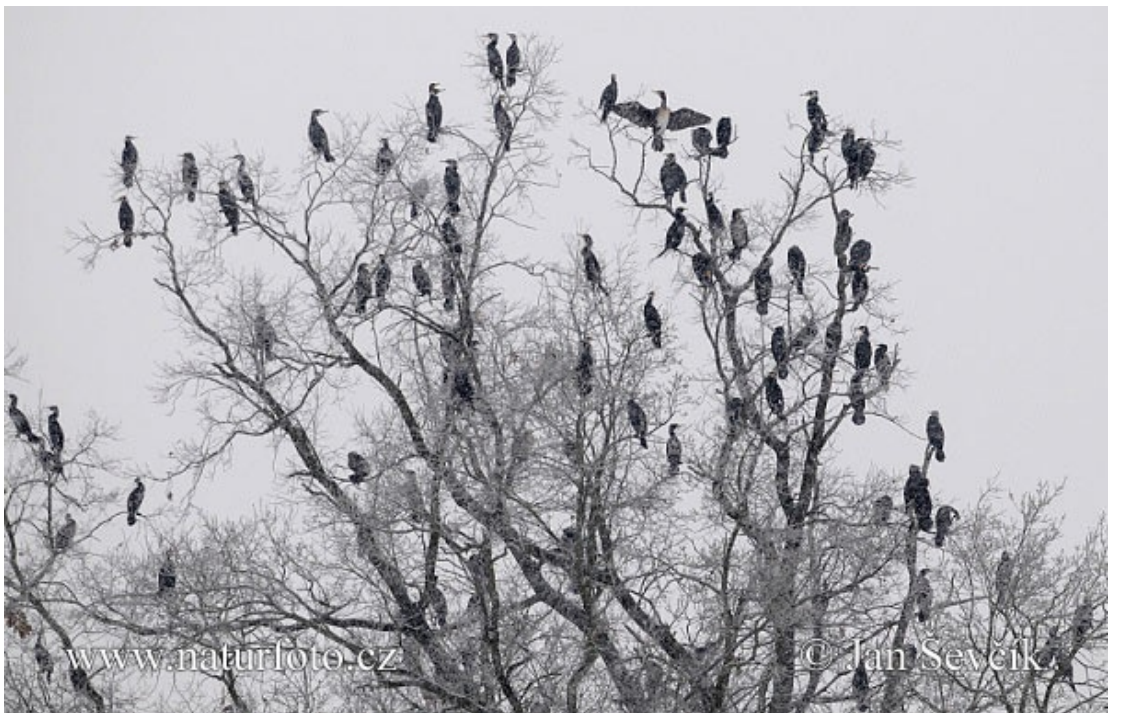

Photo 5. Cormorant colony at night stay site (Wings are not open). Source: Jan Sevcik www.naturfoto.CZ.

Zijlstra and Van-Eerden [11] observed only one regurgitation of particles a day containing only fishes preyed on during the previous 24 hours. They also confirm that the conservation Otolithes of large fishes are very well preserved in the pellets. Nevertheless, they [11] claimed that Cormorants in captivity behave significantly differently from those in natural conditions. A similar conclusion was also presented in [12].

The existence of several night stay sites in the vicinity of Lake Kinneret was documented. Several flights and landings a day of Shags, coming from different directions to Kinneret were confirmed (person commun.). Consequently, the population size was corrected from 2500 [4] to approximately 7000 with recalculating pellets counting from one per day per bird to a slightly higher value. 
Johnson and McCullough [12] carried out 8 years of research of quantitative assessment of the feeding habits of Shags (Double Crested Cormorant) in Lake Ontario. They [12] documented Shags' colonies annual consumptions on 3 Islands of $34.4 \times 10^{6}$ preyed fish weighted 5300 tons.

\subsection{The Role of Cormorants as a Top Predator}

Since the mid-1990s, the Kinneret ecosystem has undergone changes in limnology [13] [14] [15] [16]. The practical implication of Cyanobacteria blooms increase is a threat to water quality. Condition of $\mathrm{N}$ limitation and sufficient $\mathrm{P}$ is optimal for the growth of Cyanbacteria and also for Diatoms and Chlorophytes. This explains the decline in Peridinium and increase of the other phytoplankton. The decreased epilimnetic depth has been attributed to the higher frequency of droughts. These changes enhanced a change in the feeding habits of the lake fish. During its dominance, Peridinium spp. was the major food component of the most valued native fish (Sarotherodon galilaeus) in the lake. Zooplankton was the major food constituent of the endemic Bleak cyprinids (Acanthobrama terraesanctae terraesanctae, Acanthobrama lissneri). To ensure water quality, it is important to maintain high grazing pressure of zooplankton on nano-phytoplnkton. Removal of the unwanted Bleaks by biomanipulation and fishery management [15] and the introduction of the exotic Silver Carp (Hypophthalmichthys molitrix), an efficient consumer of Microcystis, is therefore beneficial. Zooplankton biomass in Lake Kinneret declined from 1970 to the early 1990s but increased thereafter. Both, the biomass and size frequency of cladocerans were affected by fish predation.

Under the modified food web structure, Tilapia is a zooplankton food source competitor with Bleaks. The reduction of Cormorant predation pressure from the Tilapia population is therefore essential.

\subsection{The Crisis of Tilapia Fishery}

During 2007-2008, Tilapia fishery in Lake Kinneret collapsed and landings declined from 200 - 400 tons annually to less than 10 tons in 2008 [17] [18]. We identified several causations for this decline: 1: Reduction of Tilapia stocking; 2 : The use of illegal fishing net mesh-sizes; 3: The disappearance of Peridinium and Cyanobacteria dominance; 4: Outbreak of Bleaks causing strong competition between Bleaks and Tilapia for their zooplankton food resources; 5: An outburst of a mysterious viral disease that is infecting mainly Tilapia (NODA virus blind eye disease); 6: Intensification of Cormorant predation; 7: Natural cycled fluctuations of Tilapias stock. Cormorant predation was only one although a significant factor among the predatory causes of the decline of Tilapias.

\section{Summary and Conclusions}

The information presented in a research about the potential impact of Cormorant on the Kinneret ecosystem that was carried out by NPA [4] was partly criticized and was completed from international resources. The number of Great 
Cormorant (Phalacrocorax carbo) wintering (from the end of October through March) in the Lake Kinneret Region is approximated as 6000 (5000 - 7000). The birds utilized several sites with big trees and bushes as night resting stations. The birds enter in big flocks throughout the early morning and noon time daily from all sites to prey on fish in the lake. The predation rate of the Cormorants indicates a daily ration varying between 300 and 1000 grams per bird with the more common value of 700 grams per bird [19] [20]. They spend time on Kinneret Beaches sites during the day time for wing dryness and probably egest their pellets too and not only in night stay sites. The feeding behavior was detected daily by Binocular and description is given. As an average predation rate value, considering international data and corrected NPA report (Artzi, Y. 2011/2012), the value of $500 \mathrm{~g}$ fish per day per bird was implemented. With regard to a seasonal change of prey composition, it is considered that, during and after arrival until the end of December (80 days), the prey comprised mostly of Bleaks and during the following 100 days (January-March) mostly sub-commercial sized Tilapia.

Six thousand Great Cormorants preying daily $500 \mathrm{~g}$ fish per bird during 100 days removed 300 tons of sub-commercial-sized Tilapia (Mostly S. galilaeus) from the lake. However, we have to take into account that the fishes preyed on are below the commercial size of $100 \mathrm{~g}$ per fish, that is to say that the potential damage is bigger (legal size $>200 \mathrm{~g} /$ fish). Individual Tilapia preyed on weighted 50 - $70 \mathrm{~g}$; if not preyed on they might grow up to commercial size within 5 - 6 months to be marketed. Consequently, the commercial value of such losses is between 1.5 and 3.0 million US\$. Such a damage to fishermen's income and ecologically to the system can be reduced by aggressive deportation of the Cormorants from Lake Kinneret and simultaneously from their night station site. The ecological contribution of Tilapia to the ecosystem aimed at water quality protection is done through the consumption of Peridinium biomass gradually reappeared recently. The recommended accompanied operation is Bleaks removal aimed at releasing zooplankton food biomass to $S$. galilaeus.

The field application of the present study is a practical design which is presently under consideration aim at achieving reduction of fish predation by cormorant without violating accepted legislations. In other words, to protect nature items together with improvement of fishery and water quality in Lake Kinneret.

\section{Acknowledgements}

Warm thanks and appreciation for assistance, data support and valuable information from field observations, and Fishery statistics are given to M. Lev-Kibbutz Ein-Gev Fishery Branch; Y. Fdida-Tiberian Fishery Organization; O. Sonin, J. Shapiro, and Z. Snovsky-Lake Kinneret Fishery Department, Agriculture Ministry.

\section{References}

[1] Takahashi, T., Kameda, K., Kawamura, M. and Nakajima, T. (2006) Food Habits of Great Cormorant Phalacrocorax carbo hanedae at Lake Biwa, Japan, with Special 
Reference to Ayu Plecoglossus altivelis altivelis. Fisheries Science, 72, 477-484. https://doi.org/10.1111/j.1444-2906.2006.01175.x

[2] Natsumeda, T., Tsuruta, T., Kameda, K. and Iguchi, K. (2010) Winter Feeding of the Common Cormorant (Phalacrocorax carbo hanedae) in Temperate River in Japan. Journal of Freshwater Ecology, 25, 41-48. https://doi.org/10.1080/02705060.2010.9664355

[3] FAO/EIFAC Final Report (2008) Occasional Paper No. 41, FAO, Rome, 34 p.

[4] Artzi, Y. (2011/2012) The Great Cormorant Feeding Habits in the Lake Kinneret Region: 2010-2011. Annual Report, Nature Protection Agency (NPA) Part A (2011) and Revised Version (2012), 17 p. (In Hebrew).

[5] Shkedy, Y., Artzi, Y., Lider, N. and Hatzofe, O. (2013) Landing Decline in Lake Kinneret Resulted by System Instability but Not by Cormorant Activity. Ecology \& Environment, 4, 32-37. (In Hebrew).

[6] Johnston, I.J., Harris, M.P., Wanless, S. and Graves, J.A. (1990) The Usefulness of Pellets for Assessing the Diet of Adult Shags Phalacrocorax aristotelis. Bird Study, 37, 5-11. https://doi.org/10.1080/00063659009477030

[7] McKay, H.V., Robinson, K.A., Carss, D.N. and Parrott, D. (2003) The Limitation of Pellet Analysis in the Study of Cormorant (Phalacrocorax spp.). Vogelwelt, 124, 227-236.

[8] Duffy, D.C. and Laurenson, L.J.B. (1983) Pellets of Cape Cormorants as Indicators of Diet. The Condor, 85, 305-307. https://doi.org/10.2307/1367066

[9] Emmrich, M. and Duttmann, H. (2011) Seasonal Shifts in Diet Composition of Great Cormorant Phalacrocorax carbo sinensis, Foraging at a Shallow Eutrophic Inland Lake. Ardea, 99, 207-216. https://doi.org/10.5253/078.099.0211

[10] Trauttmansdorf, J. and Wassermann, G. (1995) Number of Pellets Produced by Immature Cormorant Phalacrocorax carbo sinensis. Ardea, 83, 133-134.

[11] Zijlstra, M. and Van-Eerden, M.R. (1995) Pellets Production and the Use of Otolithes in Determining the Diet of Cormorant Phalacrocorax carbo sinensis. Trial with Captive Birds. Ardea, 83, 123-131.

[12] Johnson, J.H. and McCullough, R.D. (2007) Diet Composition and Fish Consumption of Double Crested Cormorant from the Pigeon Island Colonies of Eastern Lake Ontario in 2007. NYSDE Lake Ontario Annual Report 2007, 9 p.

[13] Gophen, M., Smith, V.H., Nishri, A. and Threlkeld, S.T. (1999) Nitrogen Deficiency, Phosphorus Sufficiency, and the Invasion of Lake Kinneret, Israel, by the $\mathrm{N}_{2}$-Fixing Cyanobacterium Aphanizomenon ovalisporum. Aquatic Sciences, 61, 293-306.

[14] Gophen, M. (2014) Land-Use, Albedo and Air Temperature Changes in the Hula Valley (Israel) during 1946-2008. Open Journal of Modern Hydrology, 4, 101-111. https://doi.org/10.4236/ojmh.2014.44010

[15] Gophen, M. (2015) The Impact of Available Nitrogen Deficiency on Long-Term Changes in the Lake Kinneret Ecosystem. Open Journal of Ecology, 5, 147-157. https://doi.org/10.4236/oje.2015.54013

[16] Gophen, M. (2015) Experimental Study of the Aphanizomenon ovalisporum Response to Nitrogen Fertilization in the Sub-Tropical Eu-Meso-trophic Lake Kinneret (Israel). Open Journal of Ecology, 5, 259-265.

https://doi.org/10.4236/oje.2015.56020

[17] Sonin, O., Shapiro, J. and Snovsky, Z. (1990-2015) Lake Kinneret Fisheries, Annual Reports. Sonin, O., Ed., Lake Kinneret Fishery Department Agriculture Ministry. (In Hebrew) 
[18] Gophen, M., Sonin, O., Lev, M. and Snovsky, G. (2015) Regulated Fishery Is Beneficial for The Sustainability of Fish Population in Lake Kinneret (Israel). Open Journal of Ecology, 5, 513-527. https://doi.org/10.4236/oje.2015.510042

[19] Gremillet, D., Schmid, D. and Culik, B. (1995) Energy Requirement of Breeding Great Cormorant Phalacrocorax carbo sinensis. Marine Ecology Progress Series, 121, 1-9. https://doi.org/10.3354/meps121001

[20] Hatch, J., Brown, K., Hogan, G. and Morris, R. (2000) Great Cormorant (Phalacrocorax carbo). The Birds of North America Online. 553, 1-20.

http://bna.birds.cornell.edu.proxy.lib.umich.edu/bna/species/553

\section{Scientific Research Publishing}

Submit or recommend next manuscript to SCIRP and we will provide best service for you:

Accepting pre-submission inquiries through Email, Facebook, LinkedIn, Twitter, etc. A wide selection of journals (inclusive of 9 subjects, more than 200 journals)

Providing 24-hour high-quality service

User-friendly online submission system

Fair and swift peer-review system

Efficient typesetting and proofreading procedure

Display of the result of downloads and visits, as well as the number of cited articles

Maximum dissemination of your research work

Submit your manuscript at: http://papersubmission.scirp.org/

Or contact ojmh@scirp.org 